\title{
Arthrobacter psychrophenolicus sp. nov., isolated from an alpine ice cave
}

Correspondence
Rosa Margesin
rosa.margesin@uibk.ac.at

\author{
Rosa Margesin, ${ }^{1}$ Peter Schumann, ${ }^{2}$ Cathrin Spröer ${ }^{2}$ \\ and Anne-Monique Gounot ${ }^{3}$
}

\author{
${ }^{1}$ Institut für Mikrobiologie, Universität Innsbruck, Technikerstraße 25, A-6020 Innsbruck, Austria \\ ${ }^{2} \mathrm{DSMZ}$ - Deutsche Sammlung für Mikroorganismen und Zellkulturen GmbH, Mascheroder \\ Weg 1b, D-38124 Braunschweig, Germany \\ ${ }^{3}$ Laboratory of Microbial Ecology, UMR 5557, University Claude Bernard Lyon 1, F-69622 \\ Villeurbanne-Cedex, France
}

In recent years, there has been a great increase in interest in psychrophilic bacteria, because of the realization that they hold great biotechnological potential, offering numerous economical and ecological advantages (Russell, 1998; Margesin \& Schinner, 1999; Margesin et al., 2002). A wide diversity of cold-adapted micro-organisms can be found in various cold environments. A particular cold environment is found in caves situated in cold areas. Caves in mountain areas have a constant low temperature near $0{ }^{\circ} \mathrm{C}$ and lack freeze-thaw cycles; this is favourable to the selection of cold-adapted bacteria (Gounot, 1999). Bacteria with coryneform morphology, such as Arthrobacter, are widespread among bacteria found in caves (Khizhnyak et al., 2003). Psychrophilic Arthrobacter strains were reported to be the most abundant and active bacteria in subterranean cave silts (Gounot, 1967) and were also isolated from glacier silts (Moiroud \& Gounot, 1969), Arctic soils (Juck et al., 2000) and Antarctic environments (Loveland-Curtze et al., 1999; Reddy et al., 2000, 2002; Stibor et al., 2003).

Published online ahead of print on 21 May 2004 as DOI 10.1099/ ijs.0.63124-0.

The GenBank/EMBL/DDBJ accession number for the 16S rRNA gene sequence of strain $A G 31^{\top}$ is AJ616763.
Representatives of cold-adapted Arthrobacter strains produce cold-active enzymes with interesting properties (Nakagawa et al., 2003; Stibor et al., 2003). However, there is little information on Arthrobacter strains able to degrade hydrocarbons at low temperatures, although high-G $+C$ coryneform bacteria are considered important members of hydrocarbon-degrading microbial populations (Bej et al., 2000; Juck et al., 2000; Margesin et al., 2003a). A cold-adapted representative of the genus Arthrobacter isolated from an alpine ice cave has been described recently as degrading high phenol concentrations at low temperatures (Margesin et al., 2003b). This strain was subjected to phenotypic, chemotaxonomic, genetic and phylogenetic examinations.

Strain $A G 31^{\mathrm{T}}$ was isolated from a carbonate-rich deposit collected under sterile conditions in the autumn of 1999 in an alpine ice cave (Eisriesenwelt Werfen) located in Salzburg, Austria, at about $1640 \mathrm{~m}$ above sea level. A $10 \mathrm{~g}$ sample was shaken with $90 \mathrm{ml}$ sterile $1 \%(\mathrm{w} / \mathrm{v})$ sodium pyrophosphate for $20 \mathrm{~min}$ at 350 r.p.m. Appropriate dilutions, prepared with sterile distilled water, were plated $(0.1 \mathrm{ml})$ on soil-extract agar incubated at $4{ }^{\circ} \mathrm{C}$. The medium contained $50 \%(\mathrm{v} / \mathrm{v})$ soil extract ( $\mathrm{pH} 7), 0 \cdot 05 \%$ 
$(\mathrm{w} / \mathrm{v})$ yeast extract, $0.05 \%(\mathrm{w} / \mathrm{v})$ peptone from soymeal and $1 \cdot 2 \%(\mathrm{w} / \mathrm{v})$ agar $(\mathrm{pH} 7)$.

Genomic DNA extraction and PCR-mediated amplification of the 16S rRNA gene were done as described previously (Rainey et al., 1996). PCR products were sequenced according to the manufacturer's instructions using a CEQ DCTS quick start kit (Beckman Coulter) and a CEQ8000 automatic sequencing system (Beckman Coulter). The 16S rRNA gene sequence was aligned manually with published sequences from representatives of the Actinobacteria contained in the database of $16 \mathrm{~S}$ rRNA gene sequences held by the DSMZ. The ae2 editor (Maidak et al., 1999) was used to align the $16 \mathrm{~S}$ rRNA gene sequence of strain AG $31^{\mathrm{T}}$ against the sequences of the Arthrobacter type strains available from public databases. Pairwise evolutionary distances were computed using the correction of Jukes \& Cantor (1969). The least-squares distance method of De Soete (1983) was used in the construction of the phylogenetic dendrogram from distance matrices. Bootstrap analyses were done as described by Felsenstein (1993). The phylogenetic analysis included all reported species of the genus Arthrobacter. The analysis based on the almost complete 16S rRNA gene sequence (1501 nt) of strain AG3 $1^{\mathrm{T}}$ indicated that Arthrobacter sulfureus DSM $20167^{\mathrm{T}}$ was the closest phylogenetic neighbour, displaying $98 \cdot 3 \%$ sequence similarity to strain $\mathrm{AG} 31^{\mathrm{T}}$ (Fig. 1).

A. sulfureus DSM $20167^{\mathrm{T}}$ was used as reference strain for DNA-DNA hybridization. DNA was isolated using a French pressure cell (Thermo Spectronic) and was purified by chromatography on hydroxyapatite according to the procedure of Cashion et al. (1977). DNA-DNA hybridization was carried out as described by De Ley et al. (1970), with the modifications described by Huß et al. (1983) and Escara \& Hutton (1980), using a model 2600 spectrophotometer equipped with a model $2527-\mathrm{R}$ thermoprogrammer and

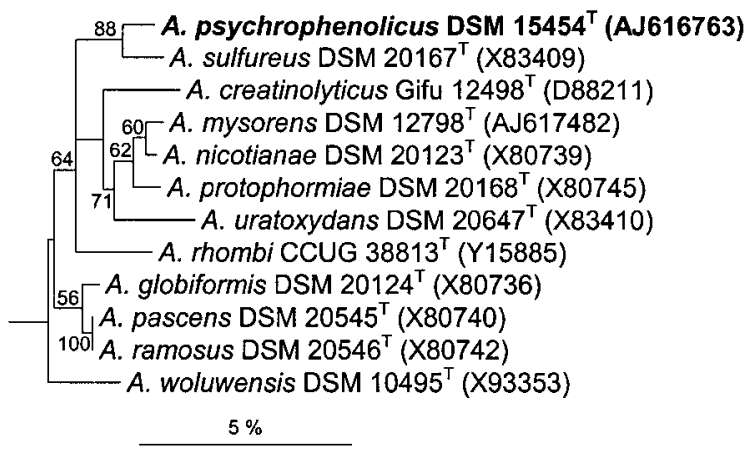

Fig. 1. Phylogenetic dendrogram based on $16 \mathrm{~S}$ rRNA gene sequences showing part of the dendrogram obtained by distance-matrix analysis of all members of the genus Arthrobacter indicating the position of $A$. psychrophenolicus DSM $15454^{\top}$. Bootstrap values higher than $50 \%$ are indicated at the relevant branching points. The scale bar represents 5 nucleotide substitutions per 100 nucleotides. plotter (Gilford Instrument Laboratories). Renaturation rates were computed with the TRANSFER.BAS program of Jahnke (1992). DNA from strain AG31 ${ }^{\mathrm{T}}$ showed only $29 \cdot 9 \%$ DNA-DNA relatedness to A. sulfureus.

Analysis of fatty acid methyl esters was performed by GLC as described by Miller (1982) and Sasser (1990). The cellular fatty acids of strain AG31 $1^{\mathrm{T}}$ grown at $25^{\circ} \mathrm{C}$ were identified as anteiso- $\mathrm{C}_{15: 0}(72 \cdot 1 \%)$, anteiso- $\mathrm{C}_{17: 0}(7 \cdot 0 \%)$, iso- $\mathrm{C}_{16: 0}(8 \cdot 3 \%)$, iso- $\mathrm{C}_{15: 0}(5 \cdot 6 \%), \mathrm{C}_{16: 0}(2 \cdot 8 \%)$, iso$\mathrm{C}_{14: 0}(2 \cdot 1 \%)$, anteiso- $\mathrm{C}_{13: 0}(0 \cdot 9 \%)$, iso- $\mathrm{C}_{17: 0}(0 \cdot 7 \%)$ and $\mathrm{C}_{14: 0}(0 \cdot 7 \%)$. The presence of significant amounts of the predominant fatty acid anteiso- $\mathrm{C}_{15: 0}$ is characteristic of representatives of the genus Arthrobacter (Keddie et al., 1986); anteiso 12-methyl tetradecanoic acid is also the predominant fatty acid in A. sulfureus (Stackebrandt et al., 1983).

The peptidoglycan structure, menaquinones and polar lipids were determined as described by Groth et al. (1997) and cell-wall sugars were analysed according to Staneck \& Roberts (1974). Analysis of the peptidoglycan structure of strain AG3 $1^{\mathrm{T}}$ revealed it to be of the A4 $\alpha$ type (Schleifer \& Kandler, 1972) with an interpeptide bridge consisting of L-Glu, type A11.54, according to the DSMZ (2001). To date, this peptidoglycan type has been reported within the genus Arthrobacter only for A. sulfureus (Schleifer \& Kandler, 1972). Strain $A G 31^{\mathrm{T}}$ contains menaquinones MK-10, MK-9 and MK-11 (ratio of peak areas, 72:12:1, respectively). A. sulfureus, the closest neighbour phylogenetically, differs from strain $\mathrm{AG} 31^{\mathrm{T}}$ in displaying MK-9 as the predominant component and possessing MK-10, MK-8 and MK-7 only in small amounts (Yamada et al., 1976). Arthrobacter nicotianae is phylogenetically related to strain $\mathrm{AG} 31^{\mathrm{T}}$ but differs in its peptidoglycan structure and menaquinone composition (Table 1). The polar lipid pattern of strain AG $31^{\mathrm{T}}$ consists of phosphatidylglycerol, diphosphatidylglycerol, phosphatidylinositol and an unidentified glycolipid. Glucose was detected as the only cell-wall sugar (Table 1).

The morphological, physiological and biochemical properties of strain $A G 31^{\mathrm{T}}$ were investigated and compared with those of A. sulfureus DSM 20167 $7^{\mathrm{T}}$. Since strain AG31 ${ }^{\mathrm{T}}$ is related to a phylogenetic cluster that was designated the 'nicotianae group' (Stackebrandt et al., 1983; Stackebrandt \& Schumann, 2000), A. nicotianae DSM $20123^{\mathrm{T}}$, as an established representative of this group of highly related Arthrobacter species, was also chosen for comparison. Morphology and motility were examined by using phasecontrast microscopy $(1000 \times)$ of cells grown on nutrient agar ( $\mathrm{pH}$ 7) plates at $25^{\circ} \mathrm{C}$ over $48 \mathrm{~h}$. Testing for the Gram reaction was carried out using classical Gram-staining and was confirmed by the $\mathrm{KOH}$-lysis test and the aminopeptidase activity test (Bactident; Merck) as described by Süßmuth et al. (1987). Sensitivity to antibiotics was determined with ATB strips (bioMérieux) incubated for up to $48 \mathrm{~h}$ at $25^{\circ} \mathrm{C}$. The biochemical profile was determined with API CORYNE and API 20NE strips (bioMérieux) incubated at $25^{\circ} \mathrm{C}$ for up to $48 \mathrm{~h}$; the profile of strain AG31 ${ }^{\mathrm{T}}$ 
Table 1. Differential phenotypic characteristics of $A G 31^{\top}, A$. sulfureus DSM $20167^{\top}$ and $A$. nicotianae DSM $20123^{\top}$

All strains are positive for the following features: Gram stain; aerobic growth; production of a yellow, non-fluorescent pigment on nutrient agar; presence of catalase, $\alpha$-glucosidase, pyrazinamidase, esterase (C4), esterase-lipase (C8) and leucine arylamidase; assimilation of maltose, gluconate, malate and citrate; tolerance of $1-3 \%(\mathrm{w} / \mathrm{v}) \mathrm{NaCl}$. All strains are negative for the following features: motility; sporulation; indole production; $\mathrm{H}_{2} \mathrm{~S}$ production from thiosulfate; presence of oxidase, arginine dihydrolase, $\alpha$-galactosidase, $N$-acetyl- $\beta$-glucosaminidase, lipase (C14), gelatin hydrolysis, trypsin, $\alpha$-chymotrypsin, $\alpha$-fucosidase, $\beta$-lactamase and pectate lyase; utilization of $n$-hexadecane or diesel oil for growth; assimilation of mannose, $\mathrm{N}$-acetylglucosamine, caprate and adipate; fermentation of glucose, ribose, xylose, mannitol, maltose, lactose, sucrose and glycogen; growth at $\mathrm{pH} 5$ and 11. All strains are susceptible to ampicillin $\left(8 \mathrm{mg} \mathrm{1}^{-1}\right.$ ) and cotrimoxazole (sulfamethoxazole + trimethoprim, $\left.16 \mathrm{mg}^{-1}\right)$ and resistant to aztreonam $\left(32 \mathrm{mg} \mathrm{l}^{-1}\right)$, ceftazidime $\left(16 \mathrm{mg}^{-1}\right)$, ciprofloxazin and norfloxazin $\left(8 \mathrm{mg}{ }^{-1}\right)$. Symbols: + , positive; - , negative; $(+)$; weak.

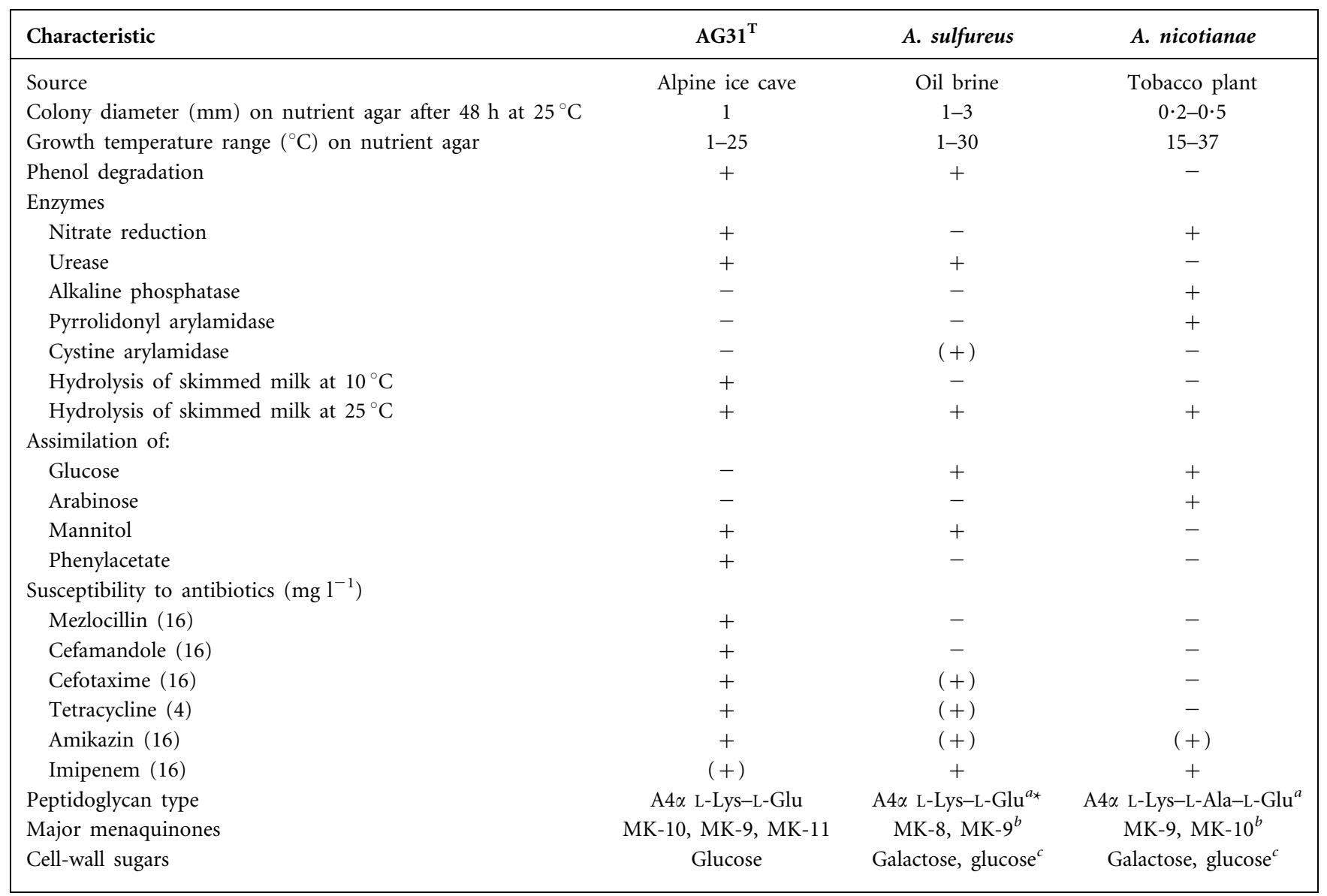

${ }^{\star}$ Data from other studies were taken from: $a$, Schleifer \& Kandler (1972); b, Yamada et al. (1976); c, Keddie \& Cure (1978).

was also determined at $10{ }^{\circ} \mathrm{C}$. The ability to utilize glucose was additionally tested by growing the strains in a $\mathrm{pH}-$ neutral minimal medium with glucose $(0 \cdot 2 \%, \mathrm{w} / \mathrm{v})$ as the sole carbon source. Thiosulfate formation, motility and indole formation were tested by using SIM agar (Süßmuth et al., 1987). The presence of enzyme activities was determined with API ZYM strips incubated at $30{ }^{\circ} \mathrm{C}$ for $6 \mathrm{~h}$. Additionally, amylase, protease, pectolytic enzymes, $\beta$-galactosidase, lipase and $\beta$-lactamase activities were tested on nutrient agar ( $\mathrm{pH} 7)$ plates supplemented with starch, skimmed milk, polygalacturonic acid (each at $0 \cdot 4 \%, \mathrm{w} / \mathrm{v})$, lactose and X-Gal $(0.2 \%, \mathrm{w} / \mathrm{v}$, and $0.004 \%$, $\mathrm{w} / \mathrm{v}$, respectively) or ampicillin $\left(50 \mu \mathrm{g} \mathrm{ml}^{-1}\right)$ as described by Margesin et al. (2003b) and incubated at 10 and $25^{\circ} \mathrm{C}$.
The properties of strain $\mathrm{AG} 31^{\mathrm{T}}$ are indicated in the species description; the diagnostic characteristics that differentiate the strain from A. sulfureus and A. nicotianae are shown in Table 1. Colonies of strain AG31 ${ }^{\mathrm{T}}$ displayed a yellow, nonfluorescent pigment on nutrient agar; this pigment was lost when the strain was grown on minimal medium agar plates with phenol as the sole carbon source. In comparison, Arthrobacter chlorophenolicus produced its pearl-grey pigment in the presence of a number of phenolic compounds only under growth conditions involving low oxygen availability (Westerberg et al., 2000). A number of species of the genus Arthrobacter, such as Arthrobacter aurescens, Arthrobacter citreus, Arthrobacter ilicis, A. nicotianae, Arthrobacter protophormiae, A. sulfureus, Arthrobacter uratoxydans, 
Arthrobacter mysorens (Stackebrandt et al., 1983; Keddie et al., 1986) and Arthrobacter flavus (Reddy et al., 2000) were described as producing a yellow pigment. On the other hand, fewer than $1 \%$ of 515 Arthrobacter strains isolated from caves were pigmented (Gounot, 1999). This might be an indication that strain $\mathrm{AG} 31^{\mathrm{T}}$ does not belong to the indigenous cave population but was probably introduced from outside, since caves visited by tourists contain a large number of introduced micro-organisms.

To determine the $\mathrm{pH}$ tolerance for growth, the strains were cultivated aerobically at 180 r.p.m. in $100 \mathrm{ml}$ Erlenmeyer flasks containing $10 \mathrm{ml}$ nutrient broth (pH 5-11). Growth at 10 and $25^{\circ} \mathrm{C}$ was monitored over $24-72 \mathrm{~h}$ by measuring the optical density at $600 \mathrm{~nm}$. The $\mathrm{pH}$ range for growth of strain $\mathrm{AG} 31^{\mathrm{T}}$ was $6-10$, with optimum growth at $\mathrm{pH} 8-10$ (corresponding to the alkaline conditions of the natural habitat). Growth of A. sulfureus and A. nicotianae was optimal at pH 7-9 and 7-8, respectively. None of the strains could grow at pH 5 or 11 .

Salt tolerance was determined by monitoring growth in nutrient broth supplemented with $1-10 \%(\mathrm{w} / \mathrm{v}) \mathrm{NaCl}$. The presence of $1-3 \%(\mathrm{w} / \mathrm{v}) \mathrm{NaCl}$ was not growth-inhibiting but actually growth-stimulating, while concentrations of 5 or $10 \%(\mathrm{w} / \mathrm{v}) \mathrm{NaCl}$ inhibited growth significantly or completely, respectively.

The effect of temperature $\left(1-37^{\circ} \mathrm{C}\right)$ on growth was examined in complex medium (nutrient broth) and in minimal medium composed of $0.35 \% \mathrm{Na}_{2} \mathrm{HPO}_{4} \cdot 2 \mathrm{H}_{2} \mathrm{O}$, $0 \cdot 2 \% \mathrm{KH}_{2} \mathrm{PO}_{4}, 0 \cdot 1 \%\left(\mathrm{NH}_{4}\right)_{2} \mathrm{SO}_{4}, 0.005 \% \mathrm{Ca}\left(\mathrm{NO}_{3}\right)_{2} \cdot 4 \mathrm{H}_{2} \mathrm{O}$, $0.001 \%$ ammonium iron(III) citrate and $0.02 \%$ $\mathrm{MgSO}_{4} \cdot 7 \mathrm{H}_{2} \mathrm{O}(\mathrm{pH} 7)$ and containing $5 \mathrm{mM}$ phenol as the sole carbon source. Growth was tested both in liquid culture and on agar plates. Strain $\mathrm{AG} 31^{\mathrm{T}}$ exhibited the properties of a facultative psychrophile (Morita, 1975), showing good growth at temperatures ranging from 1 to $25^{\circ} \mathrm{C}$. No growth occurred at $37^{\circ} \mathrm{C}$. After $24 \mathrm{~h}$ cultivation in complex medium, growth was optimal at $25^{\circ} \mathrm{C}$. After 48 and $72 \mathrm{~h}$, however, comparable cell densities were obtained at $15-25^{\circ} \mathrm{C}$ and $10-25^{\circ} \mathrm{C}$, respectively. The highest cell density was obtained at $1{ }^{\circ} \mathrm{C}$, while A. sulfureus and $A$. nicotianae produced the largest amount of biomass at $25^{\circ} \mathrm{C}$ and $20-30{ }^{\circ} \mathrm{C}$, respectively. These data demonstrate the cold-adapted character of strain $A G 31^{\mathrm{T}}$. Slow growth at $30{ }^{\circ} \mathrm{C}$ was observed only after 4 days cultivation in liquid nutrient broth culture but was not observed in nutrient agar or in liquid or solid minimal medium with phenol.

None of the strains tested could utilize diesel oil $\left(1000 \mathrm{mg} \mathrm{l}^{-1}\right)$ or $\mathrm{n}$-hexadecane $\left(700 \mathrm{mg} \mathrm{l}^{-1}\right)$ for growth, whereas both strain $\mathrm{AG} 31^{\mathrm{T}}$ and A. sulfureus degraded phenol. Strain $A G 31^{\mathrm{T}}$ fully degraded $5 \mathrm{mM}$ phenol within 2 days cultivation at $15-25^{\circ} \mathrm{C}$; full degradation had also occurred after 3 days at $10^{\circ} \mathrm{C}$ and after 7 days at $1{ }^{\circ} \mathrm{C}$. In comparison, A. sulfureus degraded phenol at temperatures below $20{ }^{\circ} \mathrm{C}$ slower than did strain AG31 ${ }^{\mathrm{T}}$.
Phenol degradation by strain $\mathrm{AG} 31^{\mathrm{T}}$ was further investigated using fed-batch cultivation in minimal medium containing phenol as the sole carbon source, whereby the same culture was recontaminated with increasing $(1-12.5 \mathrm{mM})$ phenol concentrations as soon as the phenol from the previous addition had disappeared (Margesin et al., 2003a). The strain degraded up to $7 \cdot 5 \mathrm{mM}$ phenol within 3 days at $10{ }^{\circ} \mathrm{C}$, while $10 \mathrm{mM}$ phenol was utilized within 7 days; $12.5 \mathrm{mM}$ phenol had a toxic effect. A. sulfureus even degraded $15 \mathrm{mM}$ phenol at $25^{\circ} \mathrm{C}$, which may be attributable to the natural habitat (oil brine) of the strain. Since there was no abiotic loss of phenol in sterile controls, phenol disappearance was due to biodegradation. Strain $\mathrm{AG}^{\mathrm{T}}{ }^{\mathrm{T}}$ (Margesin et al., 2003b, 2004) and A. sulfureus produced a significantly higher amount of catechol-1,2dioxygenase than of catechol-2,3-dioxygenase, indicating the preferred oxidation of catechol by the ortho type of ring cleavage.

The new strain, $A G 31^{\mathrm{T}}$, can be easily distinguished from A. sulfureus DSM $20167^{\mathrm{T}}$, the strain with the closest phylogenetic relationship, by its inability to grow at $30{ }^{\circ} \mathrm{C}$ and to assimilate glucose. Inability to assimilate glucose is rarely found with Arthrobacter strains, since more than $90 \%$ of tested strains utilized this carbon source (Keddie et al., 1986). Other characteristic properties are indicated in Table 1. Additionally, the combination of chemotaxonomic characteristics (peptidoglycan type A4 $\alpha$ with an interpeptide bridge consisting of L-Glu; MK-10 as the predominant menaquinone) serve to distinguish the novel bacterium from all recognized Arthrobacter species. Therefore, on the basis of phenotypic, phylogenetic and chemotaxonomic evidence, we propose that the bacterial strain should be classified within the genus Arthrobacter, as the type strain of Arthrobacter psychrophenolicus sp. nov.

\section{Description of Arthrobacter psychrophenolicus sp. nov.}

Arthrobacter psychrophenolicus (psy.chro.phe.no'li.cus. Gr. adj. psychros relating to cold; N.L. masc. adj. phenolicus relating to phenol degradation; N.L. masc. adj. psychrophenolicus relating to phenol degradation at low temperatures).

On nutrient agar, colonies are round, convex, glossy, with entire margins and have a yellow, non-fluorescent pigment. Cells are Gram-positive, aerobic, non-spore-forming, non-motile and exhibit a rod-coccus cycle with irregular rods in the exponential growth phase and predominantly coccoid cells in the stationary growth phase. Physiological and biochemical properties are indicated in Table 1. Good growth and phenol biodegradation occur between 1 and $25^{\circ} \mathrm{C}$ (facultative psychrophile). Fully degrades up to $10 \mathrm{mM}$ phenol as the sole carbon source. No growth occurs at $\mathrm{pH} 5$ or 11 . The predominant fatty acid $(72 \cdot 1 \%)$ is anteiso- $\mathrm{C}_{15: 0}$. The peptidoglycan type is A4 $\alpha$ L-Lys-L-Glu. MK-10 is the predominant menaquinone, while MK-9 and MK-11 occur in smaller amounts. The polar lipids are 
phosphatidylglycerol, diphosphatidylglycerol, phosphatidylinositol and an unidentified glycolipid.

The type strain is AG31 ${ }^{\mathrm{T}}\left(=\mathrm{DSM} 15454^{\mathrm{T}}=\mathrm{LMG} 21914^{\mathrm{T}}\right)$, isolated from an alpine ice cave in Werfen (Salzburg), Austria.

\section{Acknowledgements}

We thank F. Schinner for helpful discussions.

\section{References}

Bej, A. K., Saul, D. \& Aislabie, J. (2000). Cold-tolerant alkanedegrading Rhodococcus species from Antarctica. Polar Biol 23, 100-105.

Cashion, P., Holder-Franklin, M. A., McCully, J. \& Franklin, M. (1977). A rapid method for the base ratio determination of bacterial DNA. Anal Biochem 81, 461-466.

De Ley, J., Cattoir, H. \& Reynaerts, A. (1970). The quantitative measurement of DNA hybridization from renaturation rates. Eur J Biochem 12, 133-142.

De Soete, G. (1983). A least squares algorithm for fitting additive trees to proximity data. Psychometrika 48, 621-626.

DSMZ (2001). Catalogue of Strains, 7th edn. Braunschweig: Deutsche Sammlung für Mikroorganismen und Zellkulturen.

Escara, J. F. \& Hutton, J. R. (1980). Thermal stability and renaturation of DNA in dimethyl sulfoxide solutions: acceleration of the renaturation rate. Biopolymers 19, 1315-1327.

Felsenstein, J. (1993). PHYLIP (phylogeny interference package), version 3.5c. Distributed by the author. Department of Genetics, University of Washington, Seattle, USA.

Gounot, A. M. (1967). Biologic role of Arthrobacter in subterranean soils. Ann Inst Pasteur (Paris) 113, 923-945 (in French).

Gounot, A. M. (1999). Microbial life in permanently cold soils. In Cold-Adapted Organisms, pp. 3-15. Edited by R. Margesin \& F. Schinner. Berlin: Springer.

Groth, I., Schumann, P., Rainey, F. A., Martin, K., Schuetze, B. \& Augsten, K. (1997). Demetria terragena gen. nov., sp. nov., a new genus of actinomycetes isolated from compost soil. Int $J$ Syst Bacteriol 47, 1129-1133.

Huß, V. A. R., Festl, H. \& Schleifer, K. H. (1983). Studies on the spectrometric determination of DNA hybridization from renaturation rates. Syst Appl Microbiol 4, 184-192.

Jahnke, K.-D. (1992). Basic computer program for evaluation of spectroscopic DNA renaturation data from GILFORD System 2600 spectrometer on a PC/XT/AT type personal computer. J Microbiol Methods 15, 61-73.

Juck, D., Charles, T., Whyte, L. G. \& Greer, C. W. (2000). Polyphasic microbial community analysis of petroleum hydrocarboncontaminated oils from two northern Canadian communities. FEMS Microbiol Ecol 33, 241-249.

Jukes, T. H. \& Cantor, C. R. (1969). Evolution of protein molecules. In Mammalian Protein Metabolism, vol. 3, pp. 21-132. Edited by H. N. Munro. New York: Academic Press.

Keddie, R. M. \& Cure, G. L. (1978). Cell wall composition of coryneform bacteria. In Coryneform Bacteria, pp. 47-83. Edited by I. J. Bousfield \& A. G. Callely. London: Academic Press.

Keddie, R. M., Collins, M. D. \& Jones, D. (1986). Genus Arthrobacter. In Bergey's Manual of Systematic Bacteriology, vol. 2, pp. 1288-1301.
Edited by P. H. A. Sneath, N. S. Mair, M. E. Sharpe \& J. G. Holt. Baltimore: Williams \& Wilkins.

Khizhnyak, S. V., Tausheva, I. V., Berezikova, A. A., Nesterenko, E. V. \& Rogozin, D. Y. (2003). Psychrophilic and psychrotolerant heterotrophic microorganisms of middle Siberian karst cavities. Russ $J$ Ecol 34, 231-235.

Loveland-Curtze, J., Sheridan, P. P., Gutshall, K. R. \& Brenchley, J. E. (1999). Biochemical and phylogenetic analyses of psychrophilic isolates belonging to the Arthrobacter subgroup and description of Arthrobacter psychrolactophilus sp. nov. Arch Microbiol 171, 355-363.

Maidak, B. L., Cole, J. R., Parker, C. T., Jr \& 11 other authors (1999). A new version of the RDP (Ribosomal Database Project). Nucleic Acids Res 27, 171-173.

Margesin, R. \& Schinner, F. (editors) (1999). Biotechnological Applications of Cold-Adapted Organisms. Berlin: Springer.

Margesin, R., Feller, G., Gerday, C. \& Russell, N. J. (2002). Coldadapted microorganisms: adaptation strategies and biotechnological potential. In The Encyclopedia of Environmental Microbiology, vol. 2, pp. 871-885. Edited by G. Bitton. New York: Wiley.

Margesin, R., Labbé, D., Schinner, F., Greer, C. W. \& Whyte, L. G. (2003a). Characterization of hydrocarbon-degrading microbial populations in contaminated and pristine alpine soils. Appl Environ Microbiol 69, 3085-3092.

Margesin, R., Gander, S., Zacke, G., Gounot, A. M. \& Schinner, F. (2003b). Hydrocarbon degradation and enzyme activities of coldadapted bacteria and yeasts. Extremophiles 7, 451-458.

Margesin, R., Bergauer, P. \& Gander, S. (2004). Degradation of phenol and toxicity of phenolic compounds: a comparison of coldtolerant Arthrobacter sp. and mesophilic Pseudomonas putida. Extremophiles 8, 201-207.

Miller, L. T. (1982). A single derivatization method for routine analysis of bacterial whole-cell fatty acid methyl esters, including hydroxy acids. J Clin Microbiol 16, 584-586.

Moiroud, A. \& Gounot, A. M. (1969). A obligatory psychrophile bacteria isolated from glacial mud. C R Acad Sci Hebd Seances Acad Sci D 269, 2150-2152.

Morita, R. Y. (1975). Psychrophilic bacteria. Bacteriol Rev 39, 144-167. Nakagawa, T., Fujimoto, Y., Uchino, M., Takano, K. \& Tomizuka, N. (2003). Isolation and characterization of psychrophiles producing cold-active $\beta$-galactosidase. Lett Appl Microbiol 37, 154-157.

Rainey, F. A., Ward-Rainey, N., Kroppenstedt, R. M. \& Stackebrandt, E. (1996). The genus Nocardiopsis represents a phylogenetically coherent taxon and a distinct actinomycete lineage: proposal of Nocardiopsaceae fam. nov. Int J Syst Bacteriol 46, 1088-1092.

Reddy, G. S. N., Aggarwal, R. K., Matsumoto, G. I., Stackebrandt, E. \& Shivaji, S. (2000). Arthrobacter flavus sp. nov., a psychrophilic bacterium isolated from a pond in McMurdo Dry Valley, Antarctica. Int J Syst Evol Microbiol 50, 1553-1561.

Reddy, G. S. N., Prakash, J. S. S., Matsumoto, G. I., Stackebrandt, E. \& Shivaji, S. (2002). Arthrobacter roseus sp. nov., a psychrophilic bacterium isolated from an Antarctic cyanobacterial mat sample. Int J Syst Evol Microbiol 52, 1017-1021.

Russell, N. J. (1998). Molecular adaptations in psychrophilic bacteria: potential for biotechnological applications. In Advances in Biochemical Engineering/Biotechnology, vol. 61, pp. 1-21. Edited by T. Scheper. Berlin: Springer.

Sasser, M. (1990). Identification of bacteria by gas chromatography of cellular fatty acids. USFCC Newsl 20, 1-6.

Schleifer, K. H. \& Kandler, O. (1972). Peptidoglycan types of bacterial cell walls and their taxonomic implications. Bacteriol Rev 36, 407-477. 
Stackebrandt, E. \& Schumann, P. (2000). Introduction to the taxonomy of actinobacteria. In The Prokaryotes: an Evolving Electronic Resource for the Microbiological Community, 3rd edition, release 3.3. Edited by M. Dworkin, S. Falkow, E. Rosenberg, K.-H. Schleifer \& E. Stackebrandt. New York: Springer. http:// 141.150.157.117:8080/prokPUB/index.htm

Stackebrandt, E., Fowler, V. J., Fiedler, F. \& Seiler, H. (1983). Taxonomic studies on Arthrobacter nicotianae and related taxa: description of Arthrobacter uratoxydans sp. nov. and Arthrobacter sulfureus sp. nov. and reclassification of Brevibacterium protophormiae as Arthrobacter protophormiae comb. nov. Syst Appl Microbiol 4, 470-486.

Staneck, J. L. \& Roberts, G. D. (1974). Simplified approach to identification of aerobic actinomycetes by thin-layer chromatography. Appl Microbiol 28, 226-231.
Stibor, M., Potocky, M., Pickova, A., Karasova, P., Russell, N. J. \& Kralova, B. (2003). Characterization of cold-active dehydrogenases for secondary alcohols and glycerol in psychrotolerant bacteria isolated from Antarctic soil. Enzyme Microb Technol 32, 532-538.

Süßmuth, R., Eberspächer, J., Haag, R. \& Springer, W. (1987). Biochemical and Microbiological Training. Stuttgart: Thieme (in German).

Westerberg, K., Elväng, A. M., Stackebrandt, E. \& Jansson, J. K. (2000). Arthrobacter chlorophenolicus sp. nov., a new species capable of degrading high concentrations of 4-chlorophenol. Int J Syst Evol Microbiol 50, 2083-2092.

Yamada, Y., Inouye, G., Tahara, Y. \& Kondo, K. (1976). The menaquinone system in the classification of coryneform and nocardioform bacteria and related organisms. J Gen Appl Microbiol 22, 203-214. 